\title{
KERANGKA EPISTEMOLOGI (Metode Rekonstruksi Pendidikan Agama Islam)
}

\author{
Mahrus, Moh. Elman \\ Institut Agama Islam Negeri Madura, Institut Agama Islam Negeri Madura \\ mahrus.spdi@gmail.com, elmanspdi@gmail.com
}

\begin{abstract}
The epistemology of Islamic education study is an attempt to dismantle the studies that are in it, both essentially, methods, foundation, source, and validity of this Islamic education. Islamic education is a conscious effort in forming perfect individuals, namely individuals who are able to live their lives in an Islamic way. Discussion in Islamic education has three aspects, namely, aspects of faith, creed, and worship. With such a realm of morality, ethics and morals will become a major thing in Islamic education. Therefore the scope of the discussion of Islamic education is more likely to develop in accordance with the era, to make education as a balance against the development of the era by originating in faith and piety as a fundamental mentality in Islam itself.
\end{abstract}

\section{ABSTRAK}

Kajian epistemologi pendidikan Islam merupakan sebuah usaha dalam membongkar kajian-kajian yang ada didalamnya, baik secara hakekat, metode, landasan, sumber, dan validitas pendidikan agama Islam ini. Pendidikan Islam merupakan usaha sadar dalam membentuk individu yang sempurna, yaitu individu yang mampu menjalani kehidupannya secara Islami. Bahasan dalam pendidikan Islam mempunyai tiga aspek. yaitu, aspek keimanan, akidah, dan ibadah. Dengan seperti itu ranah akhlak, etika dan moral akan menjadi suatu hal yang utama dalam pendidikan Islam. Jadi, ruang lingkup bahasan pendidikan Islam lebih dimungkinkan berkembang sesuai dengan perkembangan zaman, hingga menjadikan pendidikan sebagai pengeimbangan terhadap perkembangan zaman tersebut dengan bersumber pada iman dan takwa sebagai mental fundamental dalam Islam sendiri.

\section{ARTICLE HISTORY}

Received 26 Juni 2020

Revised 01 Agustus 2020

Accepted 10 Agustus 2020

\section{KEYWORDS}

Islamic education, epistemology, value 


\section{PENDAHULUAN}

Kajian filsafat dan pendidikan merupakan kajian ilmiah yang saling mempengaruhi, bahkan dikatan dalam pendidikan akan terbangun dengan tiga kajian filsafat yang merupakan landasan dalam menyusun sistem pendidikan tersebut, yaitu dengan menggunakan kajian ontologi, epistemologi, dan aksiologi.

Dalam dunia pendidikan dan perkembangan ilmu pengetahuan, kajian epistemologis merupakan sebuah dasar dari cara berfikir rekonstruktif dan menumbuhkan mentalitas keilmuan yang sesuai dengan perkembangan zaman, maka dari itu setiap pendidikan selalu senantiasa dituntut untuk mampu mengimbangi perkembangan zaman dalam kehidupan manusia. Secara historis pendidikan Islam memiliki pengalaman dan budaya yang sebetulnya itu menjadi nilai berharga untuk menata kembali gerak dan dinamika pendidikan Islam yang berkualitas.

Berkaitan dengan filsafat dan pendidikan, Jhon S. Brubacher mengemukakan bahwa filsafat dan pendidikan mempunyai hubungan yang erat dengan problema-problema yang dihadapi filsafat, dan dalam pengembangannya pendidikan menggunakan kajian filsafat yaitu, ontology, epistemologi, dan aksiologi. ${ }^{1}$ Pengamatan Amin Abdullah, bahwa kebanyakan pendidikan Islam masih menggunakan pola konvensional-tradisional, tidak saja yang terjadi dilembaga pendidikan non formal seperti pondok pesantren dan madrasah diniyah, akan tetapi juga di sekolah Islam, madrasah dan perguruan tinggi. ${ }^{2}$ Pendidikan Islam seringkali dikesankan sebagai pendidikan yang tradisional, hal itu wajar karena dalam kegiatan pendidikan Islam, karena secara aplikatif terdapat beberapa kelemahan dalam penggunaan metodologi pembelajaran yang cenderung tidak menarik perhatian. Jika problem tersebut

\footnotetext{
${ }^{1}$ H. Jalaluddin, Filsafat Pendidikan Islam: Telaah Sejarah dan Pemikirannya (Jakarta: Kalam Mulia, 2011), hlm. 128 .

2 Muhaimin, et. al, Paradigma Pendidikan Islam: Upaya Mengefektifkan Pendidikan Agama Islam di Sekolah (Bandung: PT Remaja Rosdakarya, 2012), hlm. 90.
} 
tidak segera ditanggapi secara serius dan berkelanjutan, maka peran pendidikan Islam akan kehilangan daya tariknya.

Mujamil Qomar mengungkapkan tentang kerangka konvensionaltradisional dalam pendidikan agama Islam haruslah berupaya melakukan penggalian, penemuan dan pengembangan pendidikan Islam bisa efektif dan efisien, bila didasarkan pada epistemologi pendidikan Islam ${ }^{3}$. Sehingga segala bentuk pengembangan pendidikan Islam akan selalu berlandaskan pada hasil kajian-kajian epistemologi pendidikan Islam secara menyeluruh. Dengan artian dalam pendidikan agama Islam haruslah dilakukan kajian epitemologis yang benar, agar metodologi pendidikan agama Islam lebih mampu dalam mencapai tujuan pendidikan Islam secara maksimal.

Pendidikan Agama Islam memang harus dibangun secara epistemologis yang sesuai dengan perkembangan zaman untuk meningkatkan mutu dan daya saingnya dalam perkembangan ilmu pengetahuan. Sehingga kesesuaian metode, sumber, dan pencapaian nilai dari pendidikan Agama Islam lebih mudah dicapai kaerna kajian dalam epistimologis berkaitan dengan pertanyaan mengenai dasar pencapaian pengetahuan yang dapat dipertanggung jawabkan serta ketepatan berbagai metode mencapai kebenaran yang dapat dipercaya, maka epistimologi berperan sebagai suatu hal yang mempunyai posisi sentral dalam proses pendidikan. ${ }^{4}$

Oleh karena itu, dalam Pendidikan Agama Islam secara aplikatif (proses penerapan) harus mempunyai langkah strategi solutif yang inovatif seerta relevan dengan perkembangan zaman, sehingga isi dan metodologi pendidikan Islam menjadi aktual-kontekstual. Dengan demikian, pelaksanaan pendidikan Islam akan relevan dan sesuai dengan gerak perubahan dan tuntutan zaman.

Dalam kajian ini banyak membahas tentang beberapa hal yang di antaranya berusaha mengetahui hakekat pendidikan Islam, metode dan sumber

\footnotetext{
${ }^{3}$ Mujamil Qomar, Epistemologi Pendidikan Islam (Jakarta: Penerbit Erlangga, 2005), hlm. 207.

${ }^{4}$ George R. Knight, Filsafat Pendidikan (Yogyakarta:Gama Media, 2007), hlm. 17.
} 
dalam pendidikan Islam, serta validitas kebenaran nilai dalam pendidikan Islam dan hal lain yang mengarah pembahasan epistemologi Pendidikan Islam dalam rangka menemukan langkah rekonstruksi epitemologi pendidikan Agama Islam.

\section{METODE PENELITIAN}

Penelitian ini menggunakan jenis penelitian library research, dengan teknik pengumpulan data melalui data-data pustaka berupa teks yang terdapat di buku, artikel, makalah dan sumber-sumber tertulis lainnya. ${ }^{5}$ Penelitian ini mendeskripsian dan menganalisa tentang metode rekonstruksi pendidikan agama Islam khususnya dalam aspek epistemologi serta melakukan analisis dan kritik yang bersifat konstruktif untuk mencapai tujuan kajian yang bersifat substantif.

\section{HASIL DAN PEMBAHASAN}

\section{A. Pengertian, Ruang Lingkup dan Objek Kajian Epistemologi}

Dalam pembahasan filsafat ilmu, epistemologi, ontologi dan aksiologi merupakan subuah pembahasan yang paling mendasar dalam kajian atau bahasan tentang struktur keilmuan dan perkembangannya. Sehingga setiap jenis pengetahuan akan selalu tersusun dan berkembang dengan didasari pada tiga landasan tersebut, karena tiga landasan tersebut dalam kajian filsafat membahas mengenai apa, bagaimana, dan untuk apa pengetahuan itu ada dan tersusun. Maka dari itu, tiga bahasan ini merupakan sebuah kesatuan yanag harus ada pada ilmu pengetahuan, dan dengan tiga landasan tersebut kita akan mampu mengetahui minimalnya mana kajian teoritis dan kajian aplikatif dalam ilmu pengetahuan dan pendidikan. Secara garis besar dalam pendidikan terdapat tiga point penentu untuk keberhasilannya, yaitu Kurikulum (bentuk konsep besar), proses (aplikatif), dan evaluasi (validitas nilai). Dari hal tersebut bisa kita

\footnotetext{
${ }^{5}$ Noeng Muhadjir, Metode Penelitian Kualitatif (Yogyakarta: Rake Sarasin, 1996), hlm. 49.
} 
pahami bahwa semua ilmu pengetahuan memang pada dasarnya terbentuk dan dilandaskan pada tiga kajian filsafat yaitu ontologi (apa), epistemologi (bagaimana), dan aksiologi (nilai).

Dari hal tersebut diatas kita bisa menarik kesimpulan bahwa dalam penyusunan suatu keilmuan dilandaskan pada tiga konsepsi yang sangat mendasar yaitu, ontologi, epistemologi, dan aksiologi, sehingga ilmu pengetahuan selalu mempunyai pertanyaan mendasar tentang apa atau hakekat (ontologi), bagaimana atau metode (epistemologi), untuk apa atau nilai (aksiologi).

Dalam kajian filsafat ilmu, kajian Epistemologi merupakan sebuah kajian yang selalu membahas tentang bagaimana cara mendapatkan ilmu, atau bagaimana cara atau metode dalam memperoleh sebuah ilmu pengetahuan. Adapun pengertian epistemologi, Mohammad Adib berpendapat bahwa epistemologi merupakan ilmu yang membahas tentang pengetahuan dan cara memperolehnya, epistemologi dikatakan sebuah teori pengetahuan, yakni sebuah cabang filsafat yang membahas tentang cara memperoleh pengetahuan, hakekat pengetahuan, dan sumber pengetahuan. ${ }^{6}$ Menurut Azzumardi Azra dalam Qomar, epistemologi merupakan ilmu yang membahas tentang keaslian, pengertian, struktur, metode, dan validitas ilmu pengetahuan. Selain itu, Dagobert D. Runes dalam Qomar mendefinisikan epistemologi sebagai cabang filsafat yang membahas sumber, struktur, metode-metode dan validitas pengetahuan. Serta D.W. Hamlyn dalam Qomar juga mendefinisikan epistemologi merupakan cabang filsafat yang berurusan dengan hakekat dan ruang lingkup pengetahuan, dasar, dan pengandai-andaiannya serta secara umum hal itu dapat diandalkannya sebagai penegasan bahwa orang memiliki pengetahuan. ${ }^{7}$

Ekky al-Maliki sebagaimana yang dikutip oleh Mukhtar Sholihin, mendefinisikan epistemologi sebagai filsafat yang sistematis tentang proses

\footnotetext{
${ }^{6}$ Mohammad Adib, Filsafat Ilmu: Ontologi, Epistemologi, Aksiologi, dan Logika Ilmu Pengetahuan (Yogyakarta:Pustaka Belajar, 2010), hlm. 74.

${ }^{7}$ Qomar, Epistemologi Pendidikan, hlm. 4.
} 
mengetahui sebagai proses khas manusia. Wilayah kajiannya adalah tentang teori pengetahuan, tentang sumber (rasio-emperis), sarana, batas-batas (ruang dan waktu), struktur (subjek-objek), dan keabsahan (teori kebenaran) sebuah sistem pengetahuan. ${ }^{8}$ Dapat pula dikatakan bahwa epistemologi merupakan ilmu yang berorientasi pada persoalan-persoalan filsafat, metode dan sistem. Secara filsafat epistemologi berorientasi mencari hakikat dan kebenaran ilmu; secara metode berorientasi mengantar manusia memperoleh ilmu; dan secara sistem berusaha menjelaskan realitas ilmu dalam sebuah hirarki yang sistematis. ${ }^{9}$

Pendapat lain juga mengatakan bahwa epistemologi dapat diartikan sebagai cabang kefilsafatan yang secara khusus membahas teori ilmu pengetahuan, yang meliputi kajian pokok didalamnya, sumber pengetahuan (dari mana dan bagaimana untuk mengegtahui ilmu pengetahuan), watak dasar pengetahuan (hakekat yang terdapat dalam pengetahuaan), kebenaran pengetahuan (validitas dan verifikasi nilai pada pengetahuan). Atas dasar tersebut epistemologi dianggap sebagai studi filosofis atas dasar, metode, struktur, validitas, dan tujuan pengetahuan atau pendidikan. ${ }^{10}$

Dari beberapa pendapat tokoh diatas tentang pengertian epistemologi, maka bisa kita pahami bahwa epistemologi itu merupakan cabang kefilsafatan yang menjelaskan atau membahas masalah-masalah filosofis ilmu pengetahuan itu sendiri. Sehingga mempunyai ruang lingkup pembahsan yang meliputi hakikat, sumber, metode dan validitas ilmu pengetahuan. Atau dengan kata lain kajian epitemologi dalam ilmu pengetahuan merupakan bahasan tentang konsep dasar, proses, serta tujuan yang menjadi nilai dalam ilmu pengetahuan atau dalam system pendidikan.

\footnotetext{
8 Ekky al-Malaky, Filsafat Untuk Semua: Pengantar Mudah Menuju Dunia Filsafat (Jakarta: Penerbit Lentera, 2001), hlm. 27.

9 Mukhtar Sholihin, Epistemologi Ilmu Menurut Al-Ghazali: Studi Analisis Kitab Risalah alLaduniyah (Bandung: Puslit IAIN Sunan Gunung Jati, 1999), hlm. 26.

10 Ahmad Hasan Ridwan, Dasar-Dasar Epistemologi Islam (Bandung: Pustaka Setia, 2011), hlm. 21-22.
} 
Dalam kefilsafatan terdapat dua jenis objek yang dimiliki epistemologi, yakni objek material dan formal. Objek material adalah sesuatu yang ada, sedangkan objek formal adalah usaha mencari keterangan secara radikal tentang objek material tersebut. Maka dari itu, diasumsikan bahwa, objek material dalam kajian epistemologi ini adalah pengetahuan, sedangkan onjek formal dalam epistemologi adalah hakekat pengetahuan itu sendiri. ${ }^{11}$

Dalam perkembangan ilmu pengetahuan kajian epistemologi merupakan pengkajian yang akan membahas dalam ruang lingkup hakekat, sumber, metode, dan validitas sebuah ilmu pengetahuan yang mempunyai objek material (pengetahuan), dan objek formal (hakekat pengetahuan) dalam dunia pendidikan begitu pula dalam pendidikan agama Islam.

\section{B. Kajian Epistemologi Pendidikan Agama Islam}

Adapun kajian pada hal ini lebih fokus pada kajian tentang pengertian pendidikan agama Islam, landasan, sumber-sumber, dan tujuan pendidikan agama Islam, ruang lingkup, serta objek kajian dalam pendidikan agama Islam. Sehingga mampu mentelaah tentang kesesuain konsep dasar (kurikulum) dengan realitas keberadaan pendidikan agama Islam secara umum yang merupakan dasar dalam kebutuhan individu manusia.

Pendidikan menurut Hasan Basri merupakan proses pembinaan manusia secara jasmaniah dan rohaniah. Adapun hakikat pendidikan agama Islam dapat diartikan secara praktis sebagai pengajaran al-Qur'an dan Hadits. Secara spesifik M. Arifin menambahkan bahwa pendidikan Islam adalah bimbingan terhadap pertumbuhan jasmani dan rohani menurut ajaran Islam dengan hikmah mengajarkan, mengarahkan, melatih, mengasuh dan mengawasi berlakunya semua ajaran Islam. ${ }^{12}$ Selain itu, menurut

\footnotetext{
11 Ibid., hlm. 23.

12 M. Arifin, Filsafat Pendidikan Islam (Jakarta : Bumi Aksara, 1993), hlm. 15.
} 
Djumransjah dan Abdul Malik Amrullah menyimpulkan dari beberapa tokoh pendidikan agama Islam tentang pengertian pendidikan Islam adalah:

1. Pendidikan Islam sebagai usaha bimbingan yang ditujukan untuk mencapai keseimbangan pertumbuhan jasmani dan rohani manusia menurut ajaran agama Islam.

2. Suatu usaha untuk mengarahkan dan mengubah tingkah laku individu untuk mencapai pertumbuhan kepribadian yang sesuai dengan ajaran Islam dalam proses kependidikan melalui latihan akal fikiran (kecerdasan), kejiwaan, keyakinan, kemauan dan perasaan, serta panca indera dalam seluruh aspek kehidupan manusia.

3. Bimbingan secara sadar dan terus menerus yang sesuai dengan kemampuan dasar (fitrah) dan kemampuan ajarnya (pengaruh dari luar) baik secara individu maupun kelompok sehingga manusia mampu memahami, menghayati, dan mengamalkan ajaran Islam secara utuh dan benar(meliputi: aqidah, syariah dan akhlaq). ${ }^{13}$

Muhaimin mengatakan di dalam GBPP PAI dinyatakan bahwa pendidikan agam Islam adalah usaha sadar untuk menyiapkan siswa dalam meyakini, memahami, menghayati, dan mengamalkan ajaran agama Islam melalui kegiatan bimbingan, pengajaran, dan latihan dengan memperhatikan tuntutan untuk menghormati agama lain dalam hubungan kerukunan antar umat beragama dalam masyarakat untuk mewujudkan persatuan nasional. ${ }^{14}$

Dari beberapa pendapat para tokoh di atas tentang pengertian pendidikan agama Islam, bisa kita pahami bahwa pendidikan agama Islam itu merupakan sebuah usaha sadar dalam pengembangan manusia baik secara jasmaniyah ataupun rohaniyahnya yang sesuai dengan ajaran-ajaran agama Islam itu sendiri, sehingga manusia tersebut mampu menjadikan

\footnotetext{
${ }^{13}$ HM Djumransjah \& Abdul Malik Amrullah, Pendidikan Islam: Menggali Tradisi, Mengukuhkan Eksistensi (Malang: UIN-Malang Press, 2007), hlm. 19-20.

${ }^{14}$ Muhaimin, et. al, Paradigma Pendidikan Islam: Upaya Mengefektifkan Pendidikan Agama Islam di Sekolah (Bandung: PT Remaja Rosdakarya, 2012), hlm. 75-76.
} 
dirinya sebagai individual yang sosialis, agamis, serta edukatif dengan kata lain manusia yang sempurna.

Pendidikan agama Islam mempunyai ruang lingkup yang mencakup segala hal dalam kehidupan baik dimasa sekarang ataupun masa yang akan datang. Sehingga pendidikan Islam mempu menjadi system pendidikan yang memungkinkan manusia untuk mengarahkan segala kehidupannya sesuai dengan ideologi Agama Islam itu sendiri, atau sesorang akan mampu menjalani kehidupannya berlandaskan ajaran-ajaran Islam. Dengan demikian maka dapat dikatakan ruang lingkup Pendidikan Agama Islam berkembang sesuai dengan perkembangan zaman, sehingga ia dapat menyeimbangkan perkembangan tersebut dalam kehidupan manusia. Dengan demikian pendidikan Islam juga akan mampu mengakomodasikan tuntutan hidup manusia dari masa ke masa termasuk didalamnya adalah dalam bidang ilmu pengetahuan dan teknologi dengan sikap mengarahkan dan mengendalikan tuntutan tersebut dengan nilai fundamental yaitu bersumber dari iman dan takwa kepada Allah swt.

Landasan dalam pendidikan agama Islam adalah al-Quran dan Sunnah Rasulullah saw. yang bisa dikembangkan dengan ijma', qiyas, maslahah mursalah, saddudzsariah, urf, istihsan, dan lainnya, karena pendidikan menyangkut ruanglingkup Mua'malah. ${ }^{15}$ Dari landsan tersebut maka jelaslah pendidikan Islam itu akan meliputi pendidikan keimanan, pendidikan ibadah, dan pendidikan akhlaqul karimah, dengan kata lain pendidikan agama Islam akan membantu manusia dalam mengembangkan potensi-potensi dasar manusia yang Islami, diantaranya dengan teriptanya akhlak yang mulia, etika, dan moral yang sempurna. Menurut Said Ismail Ali mengatakan bahwa sumber dari pendidikan Islam adalah sebagai berikut:

1. Al-Qur'an

2. Sunnah Nabi, karena didalamnya mencerminkan perbuatan nabi yang patut diikuti oleh setiap muslim.

${ }^{15}$ Djumransjah \& Amrullah, Pendidikan Islam, hlm. 46. 
3. Kata-kata sahabat, karena para sahabat utamanya Khulafaur Rasyidin yang paling dekat Rasulullah dan yang menyaksikan awal munculnya Islam dan berkembangnya Islam dari masa permulaan.

4. Kemaslahatan masyarakat (sosial), karena mengacu pada pendapat AlGazali bahwa Maslahah adalah menjega tujuan agama pada manusia yang terdiri dari lima perkara, yaitu menjaga agamanya, dirinya, akalnya, keturunannya, dan harta bendanya.

5. Nilai-nilai dan kebiasaan masyarakat. ${ }^{16}$ Karena merupakan kekuatankekuatan yang mengarah pada tingkah laku individu dalam kehidupannya baik berupa perbuatan, praktek, prosedur, atau cara-cara manusia dalam menyatakan kehidupannya.

Dari beberapa sumber di atas perlu kita pahami bahwa sumber yang mendasari dari sumber yang lalinnya adalah al-Quran dan Sunnah Nabi, sebab sumber yang lainnya akan bermuara pada dua sumber utama tersebut. Sehingga keduanya selain dijadikan sumber maka juga dijadikan sebagai landasan dari pendidikan Islam.

Al-Quran sebagai sumber yang pertama dan utama, karena dalam pandangan Said Ismail Ali dalam Djumransjah dan Amrullah mengatakan bahwa karena dalam al-Quran berisi beberapa keistimewaan dalam usaha pendidikan, di antaranya:

1. Menghormati akal manusia

2. Bimbingan ilmiah

3. Tidak menentang fitrah manusia

4. Penggunaan cerita (kisah) untuk tujuan pendidikan. ${ }^{17}$

Dari beberapa hal tersebut diatas maka tujuan dari pendidikan Islam itu sendiri adalah mammpu menciptakan insan yang berwatak Islami dengan maksud mampu untuk membangun integritas antara iman, takwa,

${ }^{16}$ Ibid., hlm. 62

17 Ibid., hlm. 63 
dan intelektual dalam diri manusia, sehingga menjadi manusia yang sempurna dan menjalani kehidupannya secara islmami.

Adapun objek formal pendidikan agama Islam sebagaimana pendidikan secara umum, yakni manusia, atau lebih spesifiknya muslim. Adapun objek materialnya meliputi semua persoalan pengalaman keagamaa manusia. Dalam hal ini, materi PAI meliputi: Qur'an Hadits, Fiqih, Akidah Akhlak, dan SKI.

Menurut Hasan Basri, epistemologi pendidikan Islam merupakan seluk-beluk dari sumber-sumber pendidikan Islam sebagaimana telah ditegaskan bahwa al-Qur'an adalah segala sumber hukum dalam ajaran Islam. Pendidikan Islam merujuk pada nilai-nilai al-Qur'an yang universal dan abadi. Al-qur'an selain sebagai sumber hukum, juga digunakan sebagai penentu validitas suatu kebenaran. ${ }^{18}$ Di samping al-Qur'an, pendidikan Islam juga menggunakan sumber kebenaran lainnya yaitu as-Sunnah, atsar dan ijma' sahabat, dan ijtihad ulama. ${ }^{19}$

Membicarakan epistemologi, tidak bisa terlepas dari metode. Metode pendidikan Islam dalam hal ini membahas hakikat cara-cara kerja dalam menyusun ilmu pendidikan Islam. Di antara metode yang digunakan dalam menyusun ilmu pendidikan Islam, dengan merujuk pada sumber utama yaitu, al-Qur'an di antaranya dengan metodologi hermeneutik. Hermeneutik adalah kiat untuk memahami teks-teks keagamaan dalam pencarian melalui pencarian makna dari susunan kalimat, konteks budaya, tafsir transendensi dan yang lainnya. Menurut Noeng Muhadjir, konsep teoritiknya berangkat dari linguistik, narasi bahasa, historis, hukum, etika dan lain-lain. ${ }^{20}$

Al-Quran yang sarat dengan nilai-nilai pendidikan Islam perlu untuk diinterpretasikan dalam pencarian kebenaran kontekstual. Dalam hermeneutik, Arkoun membagi model-model teks menjadi dua, yaitu teks

\footnotetext{
18 Hasan Basri, FIlsafat Pendidikan Islam (Bandung: Pustaka Setia, 2009), hlm. 19.

19 Ibid., hlm. 149.

20 Noeng Muhadjir, Filsafat Ilmu Telaah Sistematis Fungsional Komperatif (Yogyakarta: Rake Sarasin, 1998), hlm. 85.
} 
pembentuk (naskah al-Qur'an), dan teks penjelas/hermeneutik (literaturliteratur yang memberikan interpretasi dan penjelasan terhadap teks pembentuk yang dimunculkan oleh para pemikir Islam sejak empat abad pertama hijriah hingga sekarang termasuk juga hadits Nabi saw). ${ }^{21}$

M. Solly Lubis, menyatakan bahwa dasar pengetahuan dalam pendidikan Islam ada beberapa macam, yaitu wahyu, intuisi, dan penalaran (cirinya adalah logis dan analisis). Menurutnya, wahyu dan intuisi termasuk dasar pengetahuan yang non analitis. Melalui wahyu yang disampaikan Tuhan kepada para utusan-Nya dengan perantaraan malaikat dan diteruskan kepada umat manusia, sehingga mereka memperoleh pengetahuan melalui keyakinan dan kepercayaan bahwa apa yang diwahyukan itu adalah suatu kebenaran. Demikian juga intuisi menjadi dasar pengetahuan, meskipun tidak mempunyai logika dan pola pikir tertentu.

Dalam hal ini, M. Solly Lubis kembali menjelaskan bahwa seseorang harus bisa membedakan antara kebenaran ilmiah atau filsafat dengan kebenaran agama. Kebenaran ilmiah selalu membahas sesuatu yang bersifat ilmiah dengan salah satu ciri sesuatu itu bersifat analitis, metodik, dan dinamik, sedangkan kebenaran agama juga mempermasalahkan objek-objek diluar pengalaman manusia, baik sebelum manusia berada di bumi maupun sesudah kematiannya. Perbedaan lingkup permasalahannya juga menyebabkan berbedanya metode dalam memecahkan masalah. Hal ini harus diketahui dengan benar agar mampu menempatkan keduanya dalam perspektif yang sungguh-sungguh. Dengan menguasai hakikat ilmu dengan baik, maka kedua pengetahuan tersebut justru akan bersifat saling melengkapi (komplementaristis). ${ }^{22}$

Jadi, pendidikan agama Islam selain mendasarkan pengetahuannya pada akal (rasionalisme) dan indera (empirisme), juga menggunakan hati

${ }^{21}$ M. Arkoun, Membedah Pemikiran Islam, Terj. Hidayatullah ( Bandung: Pustaka, 2000), hlm. 234. ${ }_{22}^{2}$ M. Solly Lubis, Filsafat Ilmu dan Pendidikan (Bandung: Mandar Maju, 1994), hlm. 12-14. 
(intuisi) dan wahyu sebagai sumber non-analitis. Sebagaimana yang disebutkan Hasan Basri, bahwa system pendidikan agama Islam merupakan integralitas antara unsur-unsur berikut:

1. Integralitas unsure ilahiyah, alamiah, dan insaniyah

2. Integralitas antara hati, akal, dan pancaindera sebagai alat pendeteksi kebenaran.

3. Integralitas antara ilmu pengetahuan, hidayah dan sumber ilmu pengetahuan. ${ }^{23}$

\section{Pendidikan Agama Islam menurut Epistemologi Barat}

Descartes, salah satu penganut paham rasionalisme menganggap bahwa pengetahuan memang dihasilkan oleh indera, tetapi karena dia mengakui bahwa indera itu bisa menyesatkan (seperti mimpi atau khayalan), sehingga ia membuat kesimpulan bahwa data keinderaan tidak bisa diandalkan. ${ }^{24}$ Stanley M. Honer dan Thomas C. Hunt dalam Qomar, ada tiga metode dalam mencari pengetahuan, yaitu rasionalisme, empirisme dan metode keilmuan.

1. Rasionalisme

Kaum rasionalisme mulai dengan suatu pernyataan yang sudah pasti. Adapun dasar dalam aliran ini adalah sebuah system pemikirannya (akal) yang diturunkan dari idea yang menurut anggapannya adalah jelas, tegas, dan pasti dalam pikiran manusia.

Lebih lanjut, Descartes sebagaimana yang dikutip oleh Qomar, mengenalkan pendekatan skeptisisme (kesangsian) dalam mencari pengetahuan. Sikap keraguan terhadap sesuatu dapat memotivasi timbulnya koreksi serta berkesinambungan terhadap persoalan-persoalan yang belum jelas kebenarannya. Selain itu sikap keraguan juga

\footnotetext{
${ }^{23}$ Hasan Basri, FIlsafat Pendidikan Islam (Bandung: Pustaka Setia, 2009), hlm. 152.

24 Jujun S. Suriasumantri, Ilmu dalam Perspektif (Jakarta: Yayasan Obor Indonesia, 2006), hlm. 100.
} 
mendorong seseorang untuk keluar dari keraguan sampai pada titik kemantapan (kebenaran). ${ }^{25}$

2. Empirisme

Kaum empirisme berpendapat bahwa pengetahuan manusia dapat diperoleh lewat pengalaman. Pengalaman inderawi disamping dapat memainkan perannya sebagai metode yang disebut metode empiris, juga memainkan perannya sebagai penentu validitas pengetahuan. Menurut empirisme, peran akal hanya mengkombinasikan pengalaman sehingga terbentuk pengetahuan.

Metode untuk mendapatkan pengalaman yang inheren adalah dengan penalaran induksi, yaitu proses penalaran yang bertolak dari kasus-kasus khusus untuk ditarik kesimpulan yang bersifat umum. Hasil pengetahuan yang diperoleh melalui induksi ini adalah ilmu aposteriori, yakni pengetahuan hasil pengamatan. ${ }^{26}$

3. Metode keilmuan

Metode ini merupakan jalan tengah dari kedua aliran di atas dalam mencari pengetahuan dan menguji kebenarannya. Metode ini dikembangkan kaum positivistik, yang menghasilkan metode ilmiah dengan norma metodologis sebagai berikut:

1. Semua pengetahuan harus terbukti lewat rasa kepastian, pengamatan sistematis yang terjamin secara inter subjektif

2. Kepastian metode sama pentingnya dengan rasa kepastian.

3. Ketepatan pengetahuan dijamin oleh bangunan teori secara formal kokoh mengikuti deduksi hipotesis-hipotesis yang menyerupai hukum

4. Pengetahuan harus dapat dipergunakan secara teknis

5. Pengetahuan pada prinsipnya tidak pernah selesai dan bersifat relatif. ${ }^{27}$

25 Qomar, Epistemologi Pendidikan, hlm. 59.

26 Ibid.

27 Ibid. 


\section{D.Pendidikan Agama Islam menurut Epistemologi Islam}

Kajian epistemologi memang seharusnya dilakukan secara inten dalam rangka rekonstruksi pendidikan Islam. Selain dari itu, kita bisa ketahui bahwa hakekat pendidikan islalm itu bertujuan untuk mengembangkan potensi fitrah manusia yang meliputi fitrah kognitif, afektif, dan psikomotorik, sehingga pengembangan tersebut akan menjadikan individu manusia yang benar-benar Islami, landasan dan sumber dasar al-Qur'an dan Hadist, serta ruang lingkup kajian tentang keimanan, akhlak, fiqh, dan sejarah.

Muhammad Abid al-Jabiri membagi epistemologi ilmu keislaman menjadi tiga, yaitu:

1. Epistemologi Bayani, yakni menyingkap makna dari suatu pembicaraan serta menjelaskan secara terinci hal-hal yang tersembunyi dari pembicaraan tersebut kepada taklif (orang yang terbebani hukum). Epistemologi ini menjadikan teks sebagai rujukan pokok dalam membangun konsepsi tentang alam semesta untuk memperkuat akidah Islam. Dalam memahami teks ini, segala potensi akal dikerahkan untuk mendapatkan pengetahuan maupun kebenaran, yang kemudian dikenal dengan istilah ijtihad. Adapun dalam mengimplementasikannya melalui metode qiyas (analogi) dan istinbat (penetapan kesimpulan)

2. Epistemologi Irfani, yakni pengalaman atau pengetahuan langsung dengan objek pengetahuan (ma'rifat). Epistemologi ini mulai dikenal seiring berkembangnya doktrin ma'rifat yang diyakini sebagai pengetahuan batin, terutama tentang Tuhan. Karena sumber ilmunya berasal dari pengalaman, maka metode yang digunakan adalah penghayatan intuitif, sedangkan teknik yang digunakan adalah riyadhoh. Adapun validitas kebenaran hasil pengetahuannya sulit untuk diukur menggunakan akal, karena pengalaman atau perasaan sangat subjektif. Oleh karena itu melalui simpati, empati, memahami orang lain, perlu 
dikedepankan untuk mengukur validitas kebenaran pengetahuan tersebut. Adapun akal hanya bersifat partisipatif.

3. Epistemologi Burhani, yakni Epistemologi ini menyatakan bahwa sumber atau asal pengetahuan adalah realitas, baik realitas alam, sosial, maupun kemanusiaan dan keagamaan. Pengetahuan burhani diperoleh melalui proses abstraksi dan pengamatan inderawi yang sahih. Tujuannya adalah mencari sebab dan musabab. Ukuran validitas hasil pengetahuan burhani adalah korespondensi yaitu kesesuaian antar rumus yang diciptakan manusia dengan hukum-hukum alam, koherensi yakni keruntutan dan keteraturan berpikir logis. ${ }^{28}$

Jika Pendidikan Agama Islam diurai menjadi empat aspek, yakni Qur'an Hadits, akidah akhlak, fiqih, dan SKI, maka bisa ditentukan epistemologi mana yang mendominasi antar sub-mata pelajaran tersebut. Maka Qur'an dan Hadits lebih menekankan pada epistemologi bayani, karena pembahasannya terpusat pada penafsiran teks al-Qur'an dan Hadits. Sementara akidah akhlak akan lebih didominasi pengetahuan Irfani, karena memfokuskan pada pengalaman intuisi berupa keyakinan dan pengalaman psikologi berupa sikap.

Fiqih akan berimbang antara epistemologi bayani dan burhani, karena selain menyangkut pengkajian teks dalil yang menjadi bahasan ushul fiqih, juga mempertimbangkan pengetahuan social yang menyangkut korespondensi dan koherensi dengan kondisi social kemasyarakatan. Demikian pula sejarah kebudayaan Islam, akan didominasi kedua epistemology tersebut, karena sejarah Islam selain dari teks-teks naqli (asbabun nuzul/ wurud), juga membutuhkan kesesuaian antara pengalaman inderawi dengan teks-teks kesejarahan (baik dalam hal kronologi dan periodisasi).

Dalam rangka rekonstruksi pendidikan Islam maka penulis sepakat dengan konsep pola pemikiran yang dilahirkan dari seorang tokoh

28 Ulya, Fllsafat Ilmu Pengetahuan (Kudus: STAIN Press, 2011), hlm. 120-126. 
pengamat pendidikan Islam yaitu Muhaimin mengatakan bahwa dalam proses pembelajaran pendidikan Islam seharusnya lebih menggunakan pendekatan kontekstual, yang intinya mengaitkan pembelajaran PAI dengan konteks pengalaman peserta didik yang beragam, dan konteks masalahmasalah, serta situasi-situasi riil kehidupan ${ }^{29}$.

Secara realitas dalam proses pembelajaran pendidikan agama Islam masih mempunyai kekurang yang bersifat internal yang perlu dibenahinya, diantaranya adalah PAI tidak bisa mengubah hal yang berupa pengetahuan kognitif menjadi makna dan nilai, sehingga PAI cenderung pada penekanan masalah kognitif keagamaan dalam prosesnya, pendidikan agama Islam masih terlihat terdikotomi dari pendidikan umum, dan pendidikan agama Islam kurang relevan dengan perkembangan zaman dalam kehidupan manusia, serta secara metodik lebih menggunakan pendekatan tradisional, konvensional, dan doktrinal.

Oleh karena itu, dengan kondisi semacam itu maka pendidikan agama Islam tidak akan berkembang secara signifikan. Maka dari itu dalam rangka rekonstruksi, pendidikan agama Islam haruslah menggunakan pendekatan kontestual untuk menanamkan nilai-nilai keIslaman dalam kehidupan manusia, untuk mencapai tujuan yang mengarah pada pengembangan potensi fitrah manusia, serta untuk membuat pendidikan agama Islam yang lebih relevan dengan kebutuhan manusia dan perkembangan zaman.

Dengan pendekatan kontekstual diharapkan pendidikan Islam secara pembelajarannya tidak hanya menyentuh dalam pengembangan kognitif akan tetapi akan lebih pada ranah afektif dan psikomotorik, sehingga pendidikan Islam tidak terkesan sebuah pengetahuan yang konvensional, tradisional dan doctrinal, akan tetapi dengan pendekatan kontekstual pendidikan agama Islam akan lebih dikenal dan dirasakan

${ }^{29}$ Muhaimin, Rekonstruksi Pendidika Islam (Jakarta: PT Raja Grafindo Persada, 2013), hlm. 263. 
sebuah disiplin ilmu pengetahuan yang relevan dari pperkembangan zaman serta mampu memenuhi kebutuhan manusia.

Dari hal-hal tersebut penulis bisa lebiih sepakat dengan diterapkannya pendekatan kontekstual dalam pembelajaran pendidikan agama Islam secara metodik. Akan tetapi, tantangan dalam penerapan pendekatan kontekstual ini adalah profesionalisme bagi pendidik pendidikan agama Islam yang harus mampu mengangkat realitas kehidupan yang sesuai dengan persolan yang akan disampaikan pada peserta didik, sehingga pengetahuan yang diperoleh anak didik akan lebih mampu dihayati oleh peserta didik.

Adapun rekonstruksi kedua adalah rekontruksi kurikulum yang ada, dengan cara mampu menginternalisasikan nilai-nilai keIslaman dalam pendidikan umum, sehingga dikotomi pendidikan Islam dengan pendidikan umum tidak akan terjadi. Akan tetapi kendala pada konsep kurikulum ini adalah kesulitan para guru umum untuk memmasukkan nilai-nilai keimanan dalam materi pendidikan umum.

\section{E. Pola Hubungan Tiga Bentuk Epistemologi Islam dalam Pendidikan Islam}

Dari beberapa penjelasan diatas dapat kita pahami bahwa konsep epistemologi pendidikan model bayani merupakan sebuah model keilmuan yang bergantung pada kedekatan atau kesesuaian antara teks atau nash dengan realitas, dan irfani bergantung pada pengalaman-pengalaman atau social skill sehingga terlahir rasa empati dan simpati, serta burhani yang menekankan pada korespondensi dan paragmatis. ${ }^{30}$ Maka dari beberapa bentuk epistemologi tersebut seolah-olah tidak memungkinkan untuk berjalan secara bersamaan dalam pendidikan Islam, maka dari itu dianggap sangat penting bagaimana seorang ilmuwan muslim untuk merekonstruksi

${ }^{30}$ Edi Susanto, Dimensi Studi Islam Kontemporer (Surabaya: CV. Salsabila Putra Pertama, 2014), hlm. 132. 
perjalanan tiga bentuk tersebut untuk lebih mematangkan keberagamaan umat Islam dalam memeluk agama Islam.

Menurut Edi Susanto menawarkan tiga bentuk pola hubungan dari tiga epistemologi tersebut diatas, adapun tiga tawaran tersebut adalah pola hubungan Paralel, Linier, dan Serkuler. Pola hubungan Paralel yang dimaksud adalah pola hubungan tiga bentuk epistemologi tersebut berdiri sendirisendiri, sehingga sangat sulit untuk mempertemukan antara tiga bentuk epistemologi tersebut, sehingga pola paralelisme ini berasumsikan bahwa dalam diri seorang ilmuwan Islam mempunyai tiga epistemologi sekaligus akan tetapi tidak pernah untuk mencoba mempertemukannya sehingga masing-masing dari corak epistemologi, dan Islam akan lebih bersifat kaku dalam pola hubungan ini.

Sedangakan pola hubungan linier, adalah pola hubungan yang dari awal sudah mengidolakan salah satu corak dari tiga bentuk epistemologi tersebut, sehingga dalam prosesnya pola ini akan mengalami kebuntuan dan akan lebih hegimonik dari salah satu dari tiga corak epistemologi tersebut, sehingga dalam pola ini seorang ilmuan Islam akan memarginalkan bentuk tawaran solutif dari corak yang lainnya, karena sekali lagi pola ini lebih bersifat hegemonik dari salah satu dari tiga corak tersebut dan dengan pola hubungan ini akan terjadi yang dinamakan kebuntuan scientifik dalam proses perkembangan keilmuan.

Dalam pola ini, mencoba untuk mengharmoniskan dari tiga corak epistemologi ilmu keIslaman dalam studi keIslaman, dengan artian dalam pola ini, dari masing-masing corak epistemologi menyadari atas kekurangan yang ada didalam dirinya sehingga dengan kesadaran tersebut maka akan lebih bisa untuk menerima manfaat keberadaan dari corak yang lainnya yang berpotensi untuk memperbaiki atau menyempurnakan kelemahan dan kekurangan yang ada pada salah satu corak epistemologi tersebut, sehingga dari tiga corak tersebut akan terjalin harmonisasi yang kuat dalam melakukan kajian keIslaman, dengan kata lain ketiganya sama-sama 
memanfaatkan kelebihan yang dimiliki untuk membenahi kekuranganya. Sehingga dengan pola ini maka Islam akan lebih terasa lentur, tidak kaku dan tidak cenderung untuk menutup diri dalam mengkaji realitas. ${ }^{31}$

\section{KESIMPULAN}

Pendidikan Agama Islam merupakan ilmu yang mempelajari ajaranajaran agama Islam yang berlandaskan Al-Quran dan Sunnah rasul, bersumber dari Al-Qur'an, Sunnah, Atsar dan Ijma' Sahabat, kemaslahatan masyarakat (sosial), nilai-nilai dan kebiasaan masyarakat, mempunyai ruang lingkup keimanan, akidah, dan ibadah, serta bertujuan untuk meningkatkan potensi manusia dalam menjalani kehidupannya sebagai hamba dan makhluk sosial yang bersumber pada iman dan takwa dan mampu menjalani kehidupannya secara Islami. Al-Quran dan Sunnah Rasul selain sebagai sumber pendidikan Islam, juga digunakan untuk mengukur validitas kebenaran dalam pendidikan Islam.

Maka dari itu pendidikan agama Islam mencakup empat sub mata pelajaran, yaitu Qur'an Hadits, Fiqih, Akidah Akhlak dan SKI, masing-masing sub mata pelajaran memiliki karakteristik epistemology maupun metodologi yang berbeda, namun masih kesatuan utuh sebagai pendidikan agama Islam. Epistemology dan metodologi pendidikan Islam dalam perspektif Barat dan Timur (Islam), meliputi: rasionalisme (bayan), empirisme (burhan), intuitif (irfan). Secara metodelogis dalam proses pendidikan agama Islam akan lebih efektif dalam pencapaian tujuan yang mengarah pada pengembangan fitrah manusia yang tidak hanya berupa kognitif, akan tetapi ranah afektif dan psikomotorik, maka dalam pelaksanaan proses pendidikan agama Islam diarahkan pada pendekatan kontekstual, yaitu dengan cara membuktikan kerelevanan konsep Islam dengan perkembangan zaman dengan cara mengintegrasikan realitas dengan konsep keIslaman yang ada.

${ }^{31}$ Ibid., hlm. 262-263. 


\section{DAFTAR PUSTAKA}

Adib, Mohammad. Filsafat Ilmu: Ontologi, Epistemologi, Aksiologi, dan Logika Ilmu Pengetahuan. Yogyakarta: Pustaka Belajar, 2010.

Al-Malaky, Ekky. Filsafat Untuk Semua: Pengantar Mudah Menuju Dunia Filsafat. Jakarta : Penerbit Lentera, 2001.

Basri, Hasan. FIlsafat Pendidikan Islam. Bandung: Pustaka Setia, 2009.

Djumransjah, HM dan Amrullah, Abdul Malik. Pendidikan Islam: Menggali Tradisi, Mengukuhkan Eksistensi. Malang: UIN-Malang Press, 2007.

Muhaimin, et. al. Paradigma Pendidikan Islam: Upaya Mengefektifkan Pendidikan Agama Islam di Sekolah. Bandung: PT Remaja Rosdakarya, 2012.

Muhaimin. Rekonstruksi Pendidika Islam. Jakarta : PT Raja Grafindo Persada, 2013.

Jalaluddin, H. Filsafat Pendidikan Islam: Telaah Sejarah dan Pemikirannya. Jakarta: Kalam Mulia, 2011.

Lubis, M. Solly. Filsafat Ilmu dan Pendidikan. Bandung : Mandar Maju, 1994.

M. Arifin. Filsafat Pendidikan Islam. Jakarta : Bumi Aksara, 1993.

M. Arkoun. Membedah Pemikiran Islam. diterjemahkan oleh Hidayatullah, Bandung : Pustaka, 2000.

Muhadjir, Noeng. Filsafat Ilmu Telaah Sistematis Fungsional Komperatif. Yogyakarta : Rake Sarasin, 1998. . Metode Penelitian Kualitatif. Yogyakarta: Rake Sarasin, 1996.

Qomar, Mujamil. Epistemologi Pendidikan Islam. Jakarta: Erlangga, 2005.

R. Knight, George. Filsafat Pendidikan. Yogyakarta: Gama Media, 2007.

Ridwan, H. Ahmad Dasar-Dasar Epistemologi Islam. Bandung: CV Pustaka Setia, 2011.

Sholihin, Mukhtar. Epistemologi Ilmu Menurut Al-Ghazali: Studi Analisis Kitab Risalah al-Laduniyah. Bandung : Puslit IAIN Sunan Gunung Jati, 1999.

Suriasumantri, Jujun S. Ilmu dalam Perspektif. Jakarta: Yayasan Obor Indonesia, 2006.

Ulya. FIlsafat Ilmu Pengetahuan. Kudus: STAIN Press, 2011. 